\title{
Spatial Assessment of Flood Vulnerability in Aba Urban Using Geographic Information System Technology and Rainfall Information
}

\author{
Chidi Enyinnaya Ogbonna1, Felix Ike ${ }^{2,3}$, Virginia Ugoyibo Okwu-Delunzu ${ }^{4}$ \\ ${ }^{1}$ Department of Environmental Resource Management, Abia State University, Uturu, Nigeria \\ ${ }^{2}$ Department of Geography and Planning, Abia State University, Uturu, Nigeria \\ ${ }^{3}$ Department of Geography, College of Life and Environmental Sciences, University of Exeter, Exeter, UK \\ ${ }^{4}$ Department of Geography and Meteorology, Enugu State University of Science and Technology, Enugu, Nigeria \\ Email: chiemzy@yahoo.com
}

Received 7 February 2015; accepted 5 March 2015; published 11 March 2015

Copyright (C) 2015 by authors and Scientific Research Publishing Inc.

This work is licensed under the Creative Commons Attribution International License (CC BY).

http://creativecommons.org/licenses/by/4.0/

(c) (i) Open Access

\section{Abstract}

This study investigated the relationship between topographic information and trends in rainfall in Aba urban, South Eastern Nigeria. GIS data were applied to generate topographical information on runoff characteristics, the slope, the contour, the aspect and the digital elevation model. The MannKendall Trend was applied to the rainfall data to show if a monotonic increase, decrease or stability trend exist for the rainfall data of Aba metropolis for the period 2000-2010. Results showed that virtually all parts of Aba were liable to floods expect Ogbor hill axis. The flood vulnerability map indicated that $\mathbf{7 1 . 6 5 \%}$ of the study area was vulnerable to flood. Rainfall trend showed a decrease in six out of the ten year period. Since within this period, flood intensity had generally remained the same, we concluded that topography, poor drainage infrastructure and non-compliance with building, planning and environmental regulations rather than rainfall trend were the key cause of flood problem in the study area.

\section{Keywords}

Flood Vulnerability, Rainfall Trend, GIS, Topography, Poor Drainage

\section{Introduction}

Flooding is one of the most common natural hazards particularly in river valleys, low-lying areas, and in recent time urban settlements [1]. More than any other environmental hazard, floods bring benefits as well as losses. 
Flooding occurs as a result of excessive rainfall especially on low lying areas and impermeable surfaces. Floods and other hydrologic hazards clearly show the link between climate and human use systems which frequently results in severe socio-economic, environmental and health problems in vulnerable areas and to vulnerable people [2].

Vulnerability implies the potential for loss [3] [4]. It is related to characteristics that influence an individual's or group's ability or inability to anticipate, cope with, resist, and recover from or adapt to any external stress such as the impact of flooding [5]-[7]. Vulnerability assessments have been recognized as being crucial to disaster management and are conducted to understand potential for loss, focusing on nature of the hazard and who and what are exposed [8].

From a climate change standpoint, identifying vulnerability is important for the development of mitigation strategies and adaptation policies necessary for sustainable development [9]. Vulnerability mapping can help guide flood plain zoning which like other non-structural flood control measures, which in the view of [10] are usually given less attention by environmental managers. It would appear most studies on vulnerability to floods and other hazards have been carried outside South Saharan Africa, including those of [11] [12]. However, an attempt was made by [13] in the study area.

Geographic Information System (GIS) is an important tool for mapping spatial distribution of exposure and vulnerability. It facilitates input, storage, management, analysis, integration, and output of spatial data which can help real time decision making and strategic planning for effective risk management and hazard preparedness particularly for meteorological and flood hazards [14]. GIS can be used in assessing flood impacts. GIS is a tool that can assist flood plain managers in identifying flood prone areas, helping also in real time monitoring, early warning and quick damage assessment of flood disasters.

In Nigeria, urban floods are characteristic of cities such as Aba, resulting mainly from poor planning and land use, poor drainage network and indiscriminate dumping of refuse into drains and streams among others [15]. Flooding has been a major and recurrent environmental problem in Aba. It has wide ranging environmental and socio-economic effects, and also endangers human live. Some of these effects include, damage to transport infrastructure which can disrupt transport, communication and other economic activities, damage to property and surface water pollution.

Flooding is the most common natural hazard affecting Aba urban at present. In the study area, the problem of flooding has so far been difficult to mitigate. Particularly, non-mitigation strategies are far from adequate, if at all they are implemented. There appears to be little work on flood risk and vulnerability in Aba. The most recent attempt by [15] tried to describe incidence of flooding in Aba using DEM and slope information but did not produce a flood vulnerability map. This work goes a step by not just producing a flood vulnerability map but also assessing the contribution of rainfall to flooding in Aba urban. There is as yet, no flood vulnerability map of the study area. This will be especially crucial in flood management in the study area and other flood prone settlements, structural and non-structural mitigation measure are inadequate.

The study was aimed at providing precise information on areas where people, natural environment and built environment are at risk of flooding in Aba urban based on topographic considerations, using GIS tools. In addition, the study assessed contributions of climate (rainfall) and topography to flooding in the study area. This was not necessarily a vulnerability of place approach as described by [8], since it focused on biophysical factors only. Essentially, the study involved two external biophysical factors (rainfall and topography) and one of [16] four vulnerability factors.

\section{Materials and Method}

\subsection{Study Area}

Aba urban, Figure $1\left(07^{\circ} 20^{\prime} 00^{\prime \prime E}\right.$ to $07^{\circ} 26^{\prime} 00^{\prime \prime E}$ and $05^{\circ} 2^{\prime} 30^{\prime \prime} \mathrm{N}$ and $\left.5^{\circ} 08^{\prime} 00^{\prime \prime N}\right)$, is in Abia State, South Eastern Nigeria. The climate is humid tropical characterized by high rainfall amounts of up to 2800 mm and high average maximum temperature of about $32^{\circ} \mathrm{C}$. The study area is part of the rain forest belt and is drained by the Aba River. Flooding is common in the study area during the wet season. The soil type of Aba consists of coarse sands interrupted by clay lenses of Quaternary age. It has good aquiferous potential that is only about $1500 \mathrm{~m}$ thick [17]. The study area is an important industrial and commercial area in Nigeria with a population of 820,900 [18]. Aba is characterized by relatively low elevation and near flat topography which generally reduce runoff. 




Figure 1. Satellite image of Aba urban.

\subsection{Methods}

Monthly total rainfall from 2000-2010 derived from National Root Crops Research Institute Umudike and Climate Research Unit (CRU) data (www.cru.uea.ac.uk/data) were assembled and applied in this research. The Rainfall datasets were analyzed using Minitab statistical package in order to understand rainfall trends and to compare them with indices of flood vulnerability. A macro file for Mann-Kendall $S$ was invoked and applied to the rainfall data to determine if between 2000-2010 rainfall has been increasing., decreasing or stable within Aba urban SE Nigeria. Based on the suggestion by [19], before running Kendall S on the rainfall data, we assumed that the variation in the data collection procedure were not large enough to produce a bias in the trend since Mann-Kendall requires only one data point at any point in time. 
The Mann-Kendall Trend was applied to the rainfall data to show if between the beginning and end of the raining season each year, a monotonic increase, decrease or stability trend exist for the rainfall data of study. The Mann-Kendall Trend statistic $(S)$ is dependent on the Confidence Factor (CF) and the Coefficient of Variation $(\mathrm{CoV})$. The trend is said to be decreasing if $Z$ is negative and the computed probability is greater than zero. If $Z$ is positive and the probability value is greater than the level of significance, the trend is said to be increasing. The trend is said to be stable or "no trend" if the compared probability is less than the level of significance.

The test statistic Kendall $S$ is calculated as:

$$
S=\sum_{J=1}^{n=1} \sum_{J=k+1}^{n} \operatorname{sgn}\left(x_{j}-x_{k}\right)
$$

where $x$ are the data values at times $j$ and $k . n=$ length of the dataset

$$
\begin{gathered}
\operatorname{Sgn}\left(x_{j}-x_{k}\right)=\left\{\begin{array}{ll}
+1 & \text { if }\left(x_{j}-x_{k}\right)>0 \\
0 & \text { if }\left(x_{j}-x_{k}\right)=0 \\
- & \text { if }\left(x_{j}-x_{k}\right)<0
\end{array}\right\} \\
\operatorname{Var}(s)=\left|n(n-1)(2 n+5)-\sum_{t(t-1)\left(2_{t}+5\right)}\right| / 18
\end{gathered}
$$

The standardized test statistic $Z$ is computed by:

$$
Z=\left\{\begin{array}{ll}
\frac{s-1}{\sqrt{\operatorname{van}(s)}} & \text { if } s>0 \\
0 & \text { if } s=0 \\
\frac{s+1}{\sqrt{\operatorname{van}(s)}} & \text { if } s<0
\end{array}\right\}
$$

For the Geographic Information System Analysis, Garmin GPS devices, map 76, record sheet, map of the study area and vehicle for the random movement in the field were used during fieldwork for data collection and ground trothing. Erdas Imaging, ArcMap10 and Microsoft Excel packages were used for data management. Arc map 10 spatial analyst extension was used to generate the height information from ASTER DEM satellite data of the study area at $30 \mathrm{~m}$ resolution downloaded from United State Geological Survey (USGS). Data were collected in degree, minute, seconds, imported into Microsoft Excel, subsequently converted to degree decimal, and exported into geographical information system environment using Data Base Format (DBF). A point for the imported height data was subsequently generated.

Topographical information on runoff characteristics was generated. They include; slope, contour, aspect and the digital elevation model — all data were derived from Aster DEM data obtained from satellite imageries. The contour map was interpolated at 10m interval and two dimensional (2D) formats, signifying the variations in height and co-ordinates. Contour map created showed areas with equal elevations. Grid interpolation TIN (triangulated irregular network) was carried out resulting to digital elevation model (DEM) from which slope map was created. The slope and the DEM were reclassified into high flat and low values for further analysis. The flood vulnerability area map was generated using the Boolean operation in Arc GIS Raster calculation tool. This was used to detect areas where topography is simultaneously low slope and low elevation. Using the logical expression "And", the syntax is written as follow: Flood map: (slope = low and DEM = low). The output map results to the flood vulnerability map.

\section{Results and Discussion}

\subsection{Rainfall and Topography}

Outputs from both topographic information and analysis of rainfall data are presented below.

From Figure 2, rainfall generally was high (1682 - $2420 \mathrm{~mm}$ ) throughout the period), which is characteristic of a tropical environment. Generally rainfall appears to be decreasing (Table 1) in Aba urban. 2000-2001, 2006 




Figure 2. Rainfall trends in Aba.

Table 1. Mann-Kendall Trends for Rainfall from 2000-2010 in Aba.

\begin{tabular}{ccccc}
\hline$Z$ Value & $\begin{array}{c}\text { P-Value for } \\
\text { Upward Trend }\end{array}$ & $\begin{array}{c}\text { P-Value for } \\
\text { Downward Trend }\end{array}$ & Trend \\
\hline 2000 & 0.07 & 0.47 & 0.52 & Decreasing \\
2001 & 0.28 & 0.39 & 0.61 & Decreasing \\
2002 & -1.26 & 0.90 & 0.10 & No Trend \\
2003 & -1.48 & 0.93 & 0.07 & No Trend \\
2004 & 0.74 & 0.80 & 0.20 & Increasing \\
2005 & 0.89 & 0.19 & 0.81 & Decreasing \\
2006 & 0.34 & 0.37 & 0.63 & No Trend \\
2007 & -2.53 & 0.99 & 0.01 & Decreasing \\
2008 & 0.37 & 0.33 & 0.88 & Decreasing \\
2009 & 0.65 & 0.45 & 0.69 & Decreasing \\
\hline
\end{tabular}

and 2008-2010 showed a decreasing trend that was interrupted by stability (2002-2003 and 2007) and increasing trends (2004-2005). The decrease in rainfall between 2008 and 2010 could be attributed to changes in large scale regional drivers of climate variability such as El Niño and land use change [20] [21].

\subsection{Digital Elevation Model (DEM) and Slope}

Figure 3 indicates that elevations of 3 to 67.66 are low and flat areas respectively areas, and therefore flood prone since run-off from areas of higher elevation tends to concentrate at the area of lower elevations.

The areas with lower elevation include Aba river bridge, Oghor-Hill, Ogbelu Avenue, Umuocham and Omura. It should be considered during constructions and building of other infrastructures. It is expected that areas of higher elevation, that is $67.66 \mathrm{~m}$ and above are erosion prone. From the legend of the terrain, Aba urban is relatively flat in respect of variations in height. 


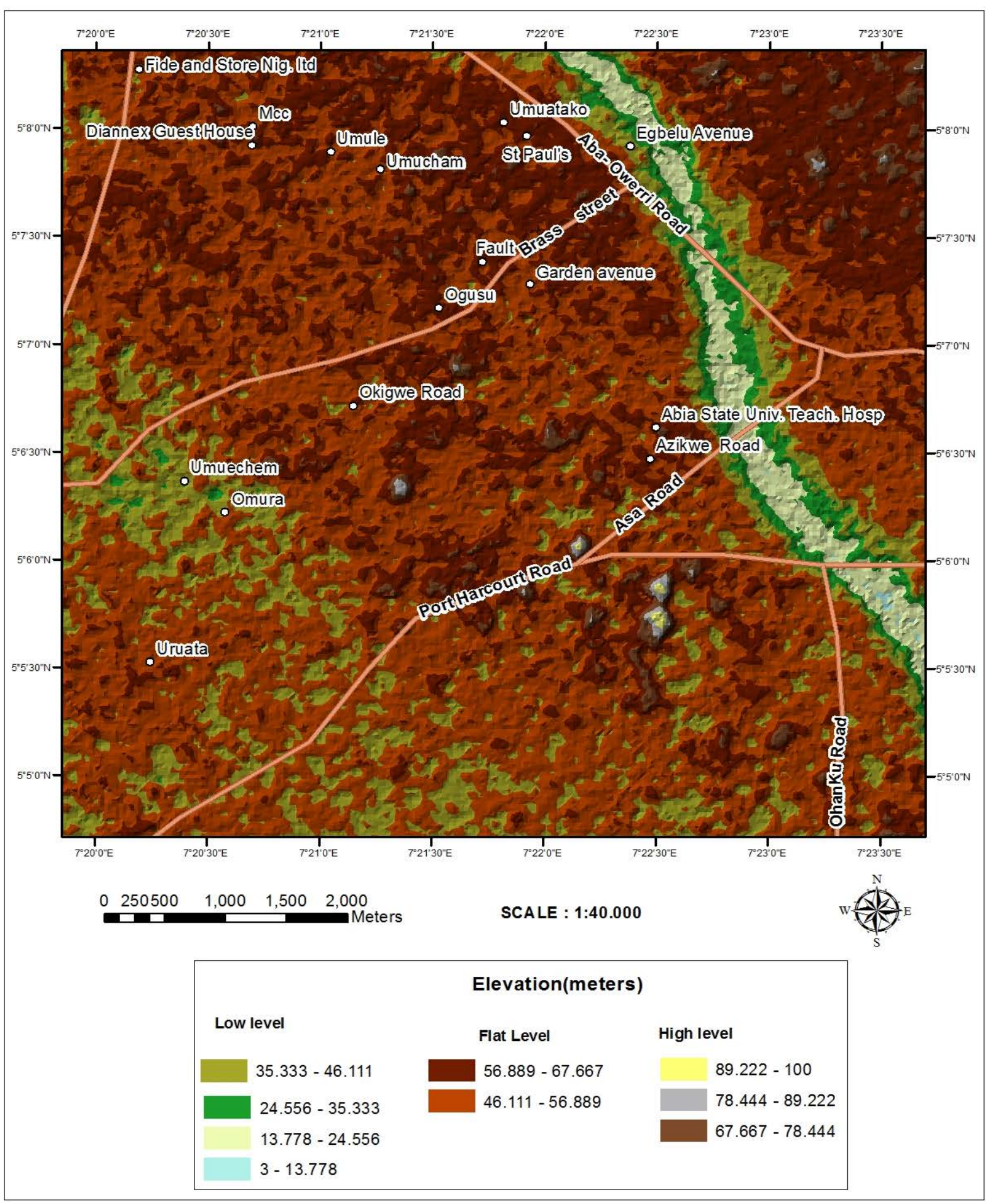

Figure 3. Digital elevation model of the study area.

Slope map identifies the overall rate of downwards movement of water. In other words, the higher the elevations, the faster the downward flow or movement of water (Figure 4). Figure 4 indicates that low slope areas (0\% $19.216 \%$ ) are flood prone, and less vulnerable to soil erosion area, owing to low runoff energy. Such areas include Ohanku road, Umuocham and Uruata. The moderate slope areas are less prone to flooding while high slope areas are flood free. 


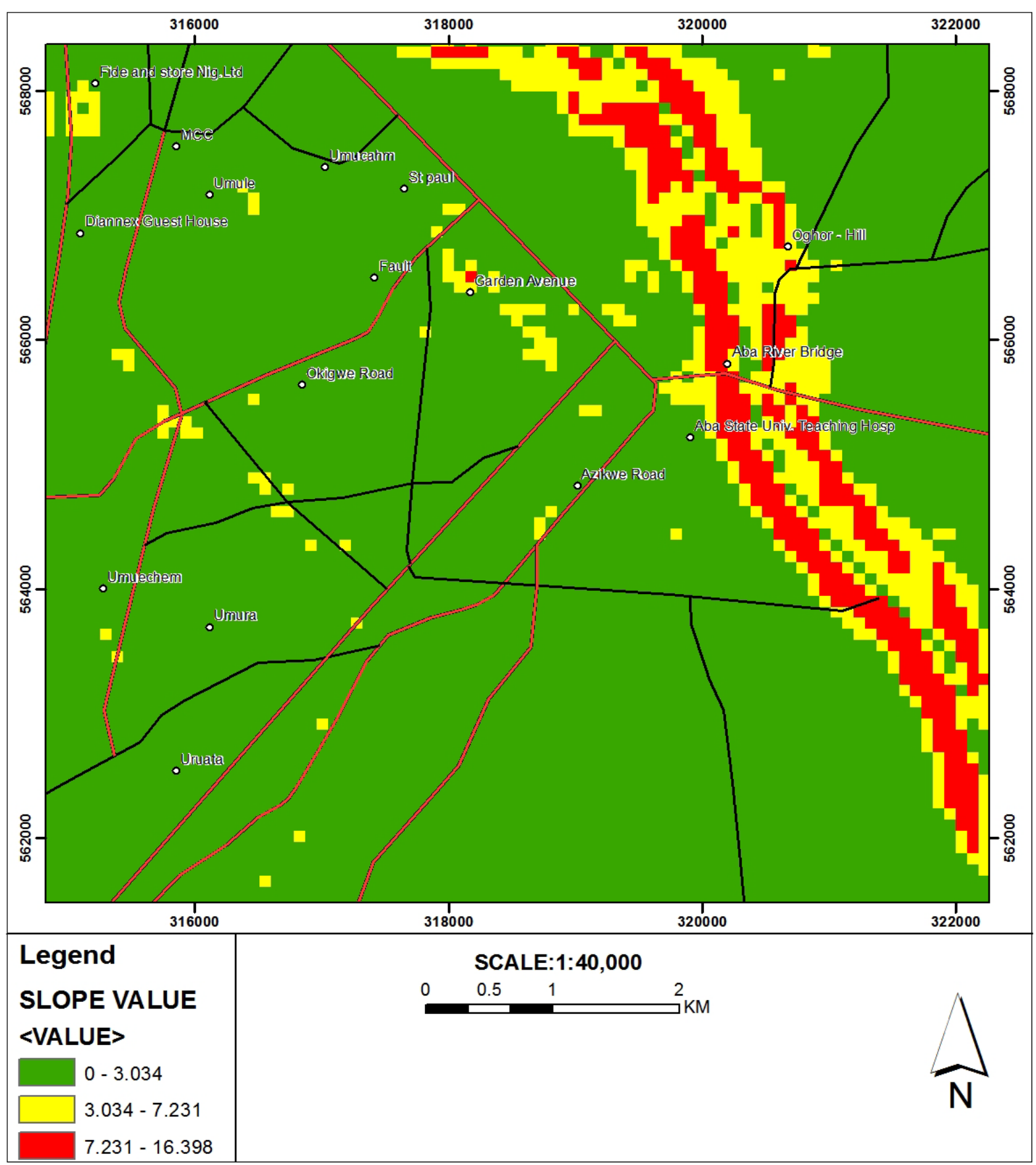

Figure 4. Slope map of Aba north metropolis, Abia State, Nigeria.

\subsection{Flood Vulnerability Mapping of the Study Area}

Flood is essentially a natural hydrological phenomenon. Generally speaking areas with low elevation and low slope are liable to flood. In Figure 5, areas in orange color are vulnerable to flood while areas in green are nonvulnerable areas. Figure 5 easily suggests that a large part Aba metropolis is liable to flood, about $72 \%$ from Table 2. This suggests severe and wide ranging effects on the study area. Based on GIS analysis, the areas liable to flood include Umuechem, Omura, Uruata, Egbelu Avenue, Oghor-Hill, Umule, Umuocham, Aba Bridge River, and Okigwe Road. Examples of resultant impacts to infrastructure include damage to Aba-Owerri road, Port Harcout Road, Asa road and Ohanku Road. Virtually all the areas liable vulnerable to flood have very high 


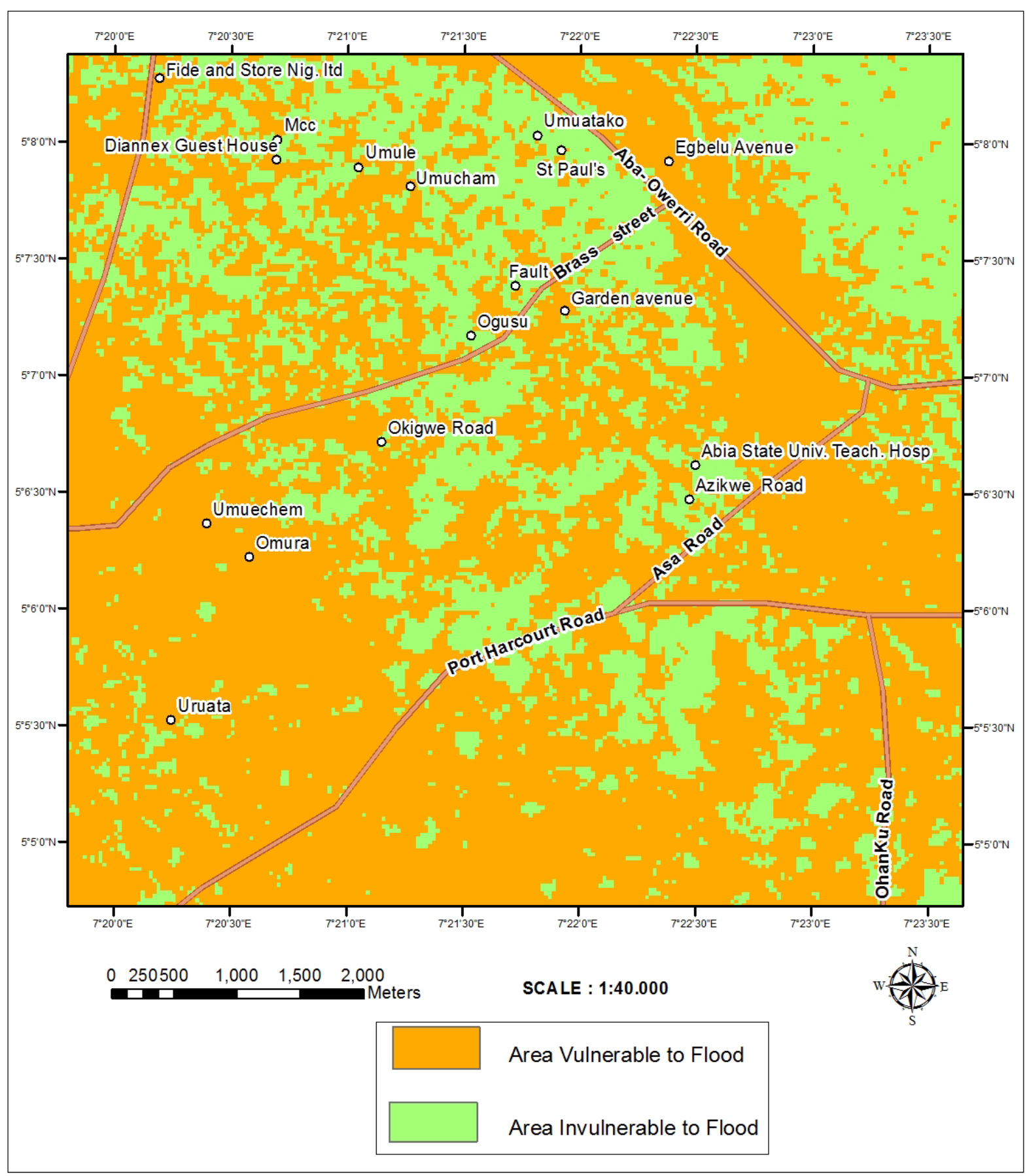

Figure 5. Map showing flood prone areas in Aba urban.

Table 2. Statistical evaluation of the flood prone areas in Aba urban.

\begin{tabular}{cccc}
\hline Code & Vulnerability & Area $\left(\mathrm{M}^{2}\right)$ & Area (\%) \\
\hline 0 & Invulnerable area & $26,606,700$ & 28.35 \\
1 & Vulnerable area & $67,245,300$ & 71.65 \\
Total & & $93,852,000$ & 100 \\
\hline
\end{tabular}


population density.

\section{Conclusion}

Flood vulnerability map developed in Aba urban by the interpolation of DEM, slope and GPS data shows that in Aba metropolis only 10 areas are liable to flood. However as correct as this result may be, during fieldwork, we observe that flooding occurs in virtually all areas in Aba metropolis with the exception of a very small area around Ogbor hill axis. From Man-Kendall analysis, rainfall has generally been on the decrease. It can be conveniently assumed that rainfall does not play a significant role in flood vulnerability in Aba. Because flood occurrence over the years has been on the increase based on fieldwork and interviews conducted during this research, therefore we suggest that the key contributing factors are topography and institutional failure covering such issues as poor drainage, waste management and a near-complete disregard for building planning and environmental regulations. This means that other factors may be responsible for flooding in Aba. Various studies have emphasized social-economic factors as being responsible for increasing trends in urban flooding. This may well be the case in Aba urban. We suggest that if institutional failure is corrected, flood vulnerability in the study area will be largely reduced.

\section{Acknowledgements}

The authors thank members and staff of the Image Processing Laboratory at Abia State University and the reviewers for useful comments and corrections.

\section{References}

[1] Smith, K. (2001) Environmental Hazards: Assessing Risk and Reducing Hazards. 3rd Edition, Routledge, New York.

[2] Daniels, T. and Daniels, K. (2003) The Environmental Planning Handbook for Sustainable Communities and Regions. Planners Press, Chicago.

[3] Cutter, S.L. (1996) Vulnerability to Environmental Hazards. Progress in Human Geography, 20, 529-539. http://dx.doi.org/10.1177/030913259602000407

[4] O’Brien, K., Eriksen, S., Schjolden, A. and Nygard, L. (2004) What's in a Word? Conflicting Interpretations of Vulnerability in Climate Change Research. CICERO Working Paper 2004-04, Center for International Climate and Environmental Research, Norway.

[5] Blaikie, P., Cannon, R., Davis, I. and Wisner, B. (1994) At Risk: Natural Hazards, People’s Vulnerability and Disasters. Routledge, New York, 284 p.

[6] Kelly, P.M. and Adger, W.N. (2000) Theory and Practice in Assessing Vulnerability to Climate Change and Facilitating Adaptation. Climatic Change, 47, 325-352. http://dx.doi.org/10.1023/A:1005627828199

[7] Montz, B. and Evans, T. (2001) GIS and Social Vulnerability Analysis. In: Gruntfest, E. and Handmer, J., Eds., Coping with Flash Floods, Kluwer Academic Publishers, Amsterdam, 37-48. http://dx.doi.org/10.1007/978-94-010-0918-8_5

[8] Cutter, S.L., Mitchell, J.T. and Scott, M.S. (2001) Revealing the Vulnerability of People and Places: A Case Study of Georgetown County, South Carolina. Annals of the Association of American Geographers, 90, 713-737. http://dx.doi.org/10.1111/0004-5608.00219

[9] Vogel, C. and O’Brien, K. (2004) Vulnerability and Global Environmental Change: Rhetoric and Reality. Information Bulletin on Global Environmental Change and Human Security, Issue No. 13. Environmental Change and Security Project and the International Development Research Centre, Ottawa.

[10] Faisal, I.M., Kabir, M.R. and Nishat, A. (2000) Non-Structural Flood Mitigation Measures for Dhaka, City. Urban Water, 1,145-153. http://dx.doi.org/10.1016/S1462-0758(00)00004-2

[11] Wu, Y.E., Yarnal, B. and Fisher, A. (2002) Vulnerability of Coastal Communities to Sea Level Rise: A Case Study of Cape May County, New Jersey, USA. Climate Research, 22, 255-270. http://dx.doi.org/10.3354/cr022255

[12] Muller, A.O., Rieter, J. and Weilman, U. (2011) Assessment of Urban Vulnerability towards Floods Using an Indicator Based Approach: A Case Study for Santiago de Chile. Natural Hazards and Earth Systems Science, 11, 2107-2123. http://dx.doi.org/10.5194/nhess-11-2107-2011

[13] Njoku, J.D., Amangabara, G.T. and Duru, P.N. (2013) Spatial Assessment of Urban Flood Risks in Aba Metropolis Using Geographic information Systems Techniques. Global Advanced Research Journal of Environmental Science and Toxicology, 2, 86-92.

[14] Chau, V.N., Holland, J., Cassells, S. and Tuohy, M. (2013) Using GIS to Map Impacts upon Agriculture from Extreme 
Floods in Vietnam. Applied Geography, 41, 65-74. http://dx.doi.org/10.1016/j.apgeog.2013.03.014

[15] Isong, M.A. (1999) Analysis of Flooding in Calabar Polytechnic and Environs. International Journal of Tropical Environment, 1, 28-37.

[16] Füssel, H-M. (2007) Vulnerability: A Generally Applicable Conceptual Framework for Climate Change Research. Global Environmental Change, 17, 155-167. http://dx.doi.org/10.1016/j.gloenvcha.2006.05.002

[17] Ebilla—Salmon and Partners Consulting Engineers (1993) Abia State Rural Water Supply Project Studies. 59-63.

[18] NPC (2013) Nigerian Population Database. Nigerian Population Commission.

[19] Flavio, P., Gianvito, Q., Gian, M.M. and Dario, C. (2008) NDVI Fluctuation from 1995-2006 in South Italy and North Africa: A Search for Climate Change Indicator. Asian Journal of Earth Science, 1, 1-15.

[20] Hulme, M., Doherty, R., Ngara, T., New, M. and Lister, D. (2001) African Climate Change: 1900-2100. Climate Research, 17, 145-168. http://dx.doi.org/10.3354/cr017145

[21] Lambin, E.F., Turner, B.L., Geista, H.J., Agbolac, S.B., Angelsend, A., Bruce, J.W., et al. (2001) The Causes of Land-Use and Land-Cover Change: Moving Beyond the Myths. Global Environmental Change, 11, 261-269. http://dx.doi.org/10.1016/S0959-3780(01)00007-3 